INTENSIVE JOURNAL

http://ojs.uniska-bjm.ac.id/index.php/EJB

E-ISSN 2620-4746

April 2021, Vol 4 No.1

\title{
TEXTBOOK AND ENGLISH TEACHER IN JUNIOR HIGH SCHOOL
}

\author{
Ridha Fadillah \\ English Education Department, Faculty of Tarbiyah and Teachers Training \\ State Islamic University "Antasari” Banjarmasin, South Kalimantan \\ ridhafadillah@uin-antasari.ac.id \\ Ariati Mufidah \\ Islamic Junior High School "Al-Fatah Sidomoro" Kebumen, Central Java \\ ariatimufidah96@gmail.com
}

\begin{abstract}
This research is intended to describe of the role of the textbook in English class. The subject of the study was English teachers in state junior high school in Banjarmasin. Data were collected through interviews, class observation, and document analysis. The investigation found that the teachers considered the textbook both central and external books helped them in preparing the lesson. They used several strategies to adapt the textbook by adding the material and modifying the task in the book. There were three main problems faced by English teachers at state junior high school 23 Banjarmasin, limited supported kits from the book, lacks materials inside the textbook, and high language level for students used in the book. However, this research is essential to conduct to present the real situation that happened in the English classroom.
\end{abstract}

Keywords: Adapted strategy; English Teacher; Textbook

\section{INTRODUCTION}

Despite the fact that innovative teaching materials are increasing, textbooks are still one of the most used teaching materials in schools. Hutchinson and Torres (1994) state that a textbook will be a helper for educators to manage the learning. For educators, the use of books is an activity that can save time, use it as a direction in education, and make it as homework materials for students. For learners, books are frameworks that help them in learning both in class and outside the class (Hutchinson

Intensive Journal, Vol. 4(1), 2021 
and Torres, 1994). In this case, learners study everything presented in the textbooks, and the manner in books present the material is the way students learn. Unfortunately, most teachers use books from the beginning to the end of the school year. The teachers then consider books to be very essential in teaching, so they use them without choosing and adapting materials that are appropriate for the learners. Therefore, it is a must for educators to select suitable materials and textbooks for learners.

However, there is no one textbook that is suitable for meeting the learning objectives to be achieved for educators and learners. This means that educators must make adaptations (Hutchinson and Torres, 1994). Educators try to adapt textbooks by adding, modifying, and removing the content, and also rearranging the context, correcting deficiencies, expanding assignments (Richards, 2001). Then, they re-create it into a more effective medium in classroom activities to get a better learning process.

Therefore, writers would like to reveal the reasons for using English textbooks in the classroom, especially at the junior high school educational levels. It is hoped that this research can disclose information about the role of English textbooks for teachers and strategies used by teachers in adapting and solving problems in adjusting material in books. So, it is expected to improve the quality of the use of books by teachers.

\section{TEXTBOOKS IN ENGLISH CLASS}

As we all know that textbooks are very instrumental in learning a foreign language in the classrooms (Richards, 2001). The following are the role of books in EFL classrooms.

Based on the experts, textbooks function as syllabus in the classrooms. As Cunningsworth (1995) asserts that textbook function as syllabi that describe predetermined learning goals. In line with Richard (2001), they functions as a syllabus that has been planned and developed systematically. Further, Cunningsworth (1995); Ur (1998); Tomlinson (2008) state that the textbook can act as a guide and source of direction for teachers in teaching.

Furthermore, Richards (2001) states that textbooks can help to standardize teaching, so that books can ensure that students in different classes with their various characteristics can receive the same content and can be evaluated in the same way. Books can also maintain the quality of teaching and learning. The case of the primary material, books tend to consist of current materials that have been tried and tested based on learning principles and are appropriate for student characteristics. Therefore, a book provides ready-made teaching texts and learning assignments (Ansary and Babaii, 2003)

O'Neil (1982) states that the use of a textbook is very efficient because it can minimize the consumption of money and time. Textbooks can reduce time-consuming in material preparation so that educators may spend much time teaching. Also, textbooks are able to help educators by applying entertaining activities, and they do not need much preparation (Hutchinson \& Torres, 1994).

Intensive Journal, Vol. 4(1), 2021 
Besides, textbooks are considered a resource that students may use to improve the language competencies and performances (Cunningswoth, 1995). They function as the primary source of language input for students to complete the input given by the teacher. Ur (1998) agrees that textbooks can help independent learning or selfassessment because students can use textbooks as a source to learn new material, and to review and monitor their progression in learning. The use of textbooks on a large scale is considered a failure of education (Swales, 1980). Richards (2001) asserts that if teachers utilize textbooks as the primary guide in teaching, then they are no more than presenters of material for students. Also, Tomlinson (2008) argues that textbooks can become a dependency on teachers so that teachers lack in teaching preparation. Finally, the teachers only teach what is in the textbook without any material modification.

So, it can be concluded that teachers who support the use of textbooks believe that textbooks can function as a syllabus of subjects, guides, and resources for teachers and students. In addition, textbooks are very efficient because they are able to minimize teacher's time in material preparation. But, teachers who disagree with the use of textbooks argue that these uses produce negative results. For example, they might not serve the needs of students or contain authentic language. Finally, the topics presented in textbooks may not be relevant and exciting for students.

After discussing the functions of the textbook, we discuss the steps in using it. According to Richards (2001), the steps are: firstly, study and understand the textbooks before starting class, find the strengths and weaknesses. Secondly, evaluate instructional assignments and materials.

So, evaluating textbooks is critical to be applied before choosing the most suitable textbooks and needs to be done continuously to ensure that every textbook used remains pedagogically effective.

After evaluating textbooks, teachers are expected to adapt and develop textbooks. Richards (2001) states that teachers should have good ability in adapting textbooks; by adapting textbooks based on students' needs, teachers have made right materials and sources for teaching. In addition, this can also make teachers more familiar with books because textbooks are subjective to adaptation when the teacher uses them in class.

According to Spratt (2005), Harmer (2007), and Richards (2001), there are eight strategies in adapting material to textbooks, they are expanding the material, changing and modifying the tasks, overcoming negligence, adding material, reducing, rewriting, replacing, and reordering the material. This can be a teacher's guide in making the material better in the teaching and learning process. Richards and Rodgers (1986) state that the material will influence various types of media in which students can use to build their competencies through various activities and tasks.

\section{RESEARCH METHODS}

This descriptive qualitative research was conducted at State Junior High School 23 Banjarmasin. This school is one of the junior high schools in Banjarmasin, 
which has implemented the main 2013 curriculum 2017 revision textbook which becomes the standard textbook used in any school according to the government has ordered. This is the reason why writers chose the school as the place of research. English teachers and students were the respondents in obtaining the information by interviewing, observing, and analyzing the documents.

\section{FINDINGS}

Based on the observation, most of the students were participating in the classroom, and a small part of them did not listen to the teacher or feel sleepy during the teaching and learning process. The teachers also explained the lesson by writing it down on the whiteboard using the external book and just using the main book a little. The learning methods that the teacher used were also connected with the main textbook because all students have the textbook as well.

a.) Teacher I

The first observation was conducted at the F class where the Teacher was taught that class; when entering the class, she didn't ask the students to open the book straightly. First, she did some warming up by asking the students about the lesson they had learned a week before. Then the Teacher introduced the chapter by asking them to open the textbook in Chapter VII, the textbook itself only introduces the topic of learning a sentence for habitual action then the book explains what kind of material that the students will learn within the next page, which is:

To communicate states and events that happen routinely or as a general truth, in order to appreciate nature, to show our pride in something, or to give good and bad samples (Wahidah et al., 2017).

During the first session, Teacher I didn't use much media to teach the class; she only brought the external textbook to explain the formula of making simple present tense because the main textbook didn't provide the material. She used the main textbook for introducing the topic and for some exercises. The teacher focused on teaching grammar. She said that her students were still having some difficulties in making simple present tense, so she was trying to recall the previous material by giving them some formulas and examples before entering the main material.

For the assignment, the teacher gave the exercise related to the simple present tense, namely making sentences and translating it to Indonesian. Then the teacher asked the students to make some sentences related to their daily activity by taking some examples from the book.

It seems that the students did not have difficulties in answering the exercise from the teacher because the teacher already explained the formula. They also liked the material from the textbook because it was explaining the zoo and animal. Some students who have difficulties answering the question often asked the teacher about the meaning rather than open their dictionary.

Intensive Journal, Vol. 4(1), 2021 


\section{b.) Teacher II}

Teacher II is a discipline person, so the students paid attention to the teacher, and the class was controlled. Same as Teacher I, Teacher II also opened the class with some warming up, playing some games for vocabulary related to the topic of the material. Then she connected the game and introduced the topic to the students.

The activities showed that Teacher II used student center approach. One of the media she used in her classroom was printed images by the students related to daily activities, then making some sentences based on the pictures they have. She liked to do some grouping to answer the work. Some of the activity and the assignment she used were based on the main textbook, such as reading some dialogues, translating vocabulary, answering questions, and also making sentences based on the topic from the chapter.

The other media used by the teacher was the external book and a printed picture for the assignment; she used the external textbook to explain some formulas related to the simple present tense and also explaining some material about vowels.

During the observation the students were still focusing on the teachers' explanation. They were excellent at answering the exercises from the teacher; some of them could find the sentence references easily from the main textbooks, and only a little of them who have some difficulties translating the vocabulary inside the textbook.

Another observation focused on seeking how many degrees of the frequency of using the textbook, teacher strategy in using the textbook, and also the type of adaptation that the teacher uses during the teaching and learning process.

a.) Teacher I

She used the textbook for introducing the material; she often used the external textbook for additional information because it contained a lot of explanation about the formula and various exercises, she also gave external information based on her presentation and asked students to write down the explanation on their books, she did it to make sure that the students would remember the lesson when she gave them exercises later.

For another activity, she preferred to do some modification based on the main textbook and apply it to the students; some games and warming up exercises could help the students be more focused on her class. Most of the exercises were very simple because the level of her students was still low. For the main exercise the teacher preferred to take an example from the external textbook because she wanted her students to focus in understanding the basics of simple present tense first then going on to the main material in the main textbook.

Most of the presentation was based on the teacher itself, sometimes she took an example from the main textbook to make some analogy from what they were going to learn. The rest of the presentation mainly focused on creating a sentence and knowing the formula about it.

b.) Teacher II

Intensive Journal, Vol. 4(1), 2021 
She often used the main textbook for her teaching, starting from introducing the material, giving an explanation, and the exercise. She was focusing on the main textbook because she felt that her students could easily understand the topic with a communicative approach. So she began the class by warming up and took some material from the main textbook.

To explain the material; she used some materials from the external books; she also took several from the main book to make some connections so that it would not be too much far from the topic. The main focus was to make sure that the students understand what they learned and wrote the material so they would not forget them.

She also added some materials like giving an example about the vowel, the formula of simple present tense, and sentence samples. Even though she often used the main textbook, she still passed a few pages from the book and added the material from the external textbook.

It shows that both teachers mostly used the external book for teaching and made an adaptation as a strategy when they found the materials on the textbook were not suitable for their student's needs. They made some materials addition from the external textbook for teaching when the textbook was insufficient; also, they modified assignments when the task was not suitable for the students' needs. But Teacher 1 also modified content while Teacher 2 was addressing omission for adaptation.

Base on the interview to the teachers, it shows:

\section{a.) Teacher I}

She used the main textbook because the book serves as a guide for her teaching in the classroom. So it would help her to teach effectively without having to add a lot of additional explanation for her students. She said that:

.... selalu. Karena itu merupakan komponen penting dalam setiap pembelajaran, jadi ketika guru termasuk saya sebelum mengajar yang penting dan harus selalu dipersiapkan adalah buku penunjang. Buku tsb adalah memang yang dipersiapkan oleh sekolah untuk menunjang agar proses pembelajaran lancar....

(Because textbooks are essential components in learning, as a teacher, I always prepared that supporting books before teaching. The book is prepared by the school to keep the learning process smoothly)

Besides, she also used the external textbook as additional information when the main textbook could not provide the material. She often used the main textbook only to introduce the topic, giving some assignments or practicing students reading skills such as reading a dialogue. She also shared that using textbook inside the classroom could help the teacher teach effectively because when she started to teach, the textbook helped her maintain what she wanted to deliver to the students.

As experienced teacher, it was easy to her for adapting the new material from the textbook, she did not have difficulties in preparing the new lesson for her students because sometimes she could take it from the main textbook and developed it on her own way. She mentioned that:

Intensive Journal, Vol. 4(1), 2021 
....karena menurut saya saya sudah terbiasa dengan materi yang ada jadi menurut saya hal tersebut mudah untuk dilakukan mengingat materi yang dipresentasikan sudah cukup familiar bagi saya sebagai pengajar. Kecuali untuk materi tertentu misalnya materi yang berhubungan dengan text bacaan, nah biasanya saya memerlukan waktu lebih untuk mempelajarinya karena saya biasanya menambahkan beberapa materi agar pembelajaran di kelas lebih menarik untuk para siswa....

(I think it is easy to adapt the material from the textbook, because as a teacher, I am familiar enough with them. Except for specific material such as material related to reading text, it usually takes more time to learn it because I usually add some materials to make learning interesting for the students)

b.) Teacher II

She thought the material inside the main textbook was not enough explanation for her students, she said that:

....Mereka (buku utama) hanya memberi tahu kita akan belajar tentang rutinitas, rutinitas kan berarti present tense, tetapi mereka (buku utama) tidak membuat rumusan tentang present tense, contoh-contoh perubahan kata kerjanya seperti apa tidak dibuat nah yang seperti itu memang tidak ada. Jadi disini menurut saya sangat kurang.

(The main book only states that we will learn about routines; the routines mean the present tense, but the main book does not formulate the present tense and does not have examples of changes of a verb. So I think it is not enough).

She used additional material from an external textbook or the internet because her students could not easily understand the material because sometimes the main textbook made them confuse and without the teacher's explanation, they would not understand how to answer the exercise inside the textbook. So it was very crucial to her using the external book, and the internet to develop her teaching and learning process.

Also, the teachers still had some difficulties in using textbooks in the teaching and learning process.

a.) Teacher I

She only had a concern about the lack of material inside the textbook. She found that the grammatical review provided by the main textbook was not enough to cover the materials given. So the teacher needed to find out more grammatical references from the external textbook. She said that:

....cuman dari segi ke lengkapan material yang saya rasa kurang kemudian justru menurut saya yang mengalami kesulitan disini itu si siswanya ya karena kan ada beberapa kalimat yang mereka belum paham misal di

Intensive Journal, Vol. 4(1), 2021 
dalam kalimat habitual action itu bagaimana grammarnya mereka (buku) ngga ngasih penjelasan mendetail....

(in terms of material completeness, I feel it incomplete so that the students will face difficulties, because there are some sentences that they do not understand; for example, in the habitual action sentence, the book does not explain it in detail)

In this case, she should develop the existing material to lead students to understand the whole material and exercise presented in a textbook or by teachers. She usually added some materials from the external textbooks or used the internet to explain the material.

b.) Teacher II

She claimed that the language level in textbooks was slightly high for their students based on their students' abilities. Though this book was made for improving students' vocabulary mastery; she thought that the language level in the textbook was still slightly higher for students. She said:

....kalo kesulitan kurang lengkap sangat kurang lengkap, terutama pada segi material serta bahasa dari buku yang cukup tinggi dan kadang membuat siswa bingung karna kan anak-anak masih rendah vocabnya kan jadi agak susah buat mereka untuk memahaminya...

(the language used in the book is too high for the students, so it makes students confused because they are still low in English vocabulary. It will be difficult for them to understand it)

Besides the language problem, the teacher was also faced with the problem related to the media or aids in the teaching and learning process. She complained that the main textbook was not completed with supported complement material such as CD or cassette. She said:

....kadang kan ketika kita mau belajar listening bukunya ngga dikasih kaset atau apa segala macam jadi kalo mereka mau belajar listening ya kita mesti ambil materi dari luar..

(Sometimes when we want to learn listening, the book was not completed with a cassette or CD, so if we are going to learn the lesson, we should take material outside the main book)

From the interview, it shows that both teachers still have difficulties in applying the textbook, namely about the content, language, and media. Both teachers maintained all those difficulties by adding, omitting, modifying, and reorganizing those materials to adapt to the class environment and students' needs.

\section{DISCUSSION}

From the data findings on teacher's ways of using textbooks, both teachers used the main textbook to accompany the external textbook as a major book to explain 
the material inside the classroom. They both used the main textbook as a framework of learning. Because of the lack of material inside the textbook, the teachers made some adaptation when they were teaching inside the classroom. The types of adaptation that the teacher used was based on what the teacher saw from the students' need. Before they applied the whole textbook material into the classroom, they needed to evaluate the textbook and made some adaptation to make their students felt comfortable to learn inside the classroom. It is obvious that the teacher made adaptation by adding material, and modifying the task was to help the students in understanding the lesson easily. This is in line with Aminuddin (2009) and Diniah (2013), who found that adaptations of a textbook that meet the students' needs can improve students' skills in learning English.

Besides, adapting textbooks is one of the abilities that teachers should have. According to Richards (2001), Spratt (2005), and Harmer (2007), there are several strategies in adapting the textbook, such as modifying or changing the form of tasks, addressing omission, adding material, and rewriting.

Furthermore, the textbook also helped teachers in managing their lessons in classroom activities. Both teachers received several advantages from textbook such as textbook act as guideline book for teachers, they provide a variety of learning resources, and helped in planning instruction. But implicitly, the reason why teachers used textbooks as guidance was that teachers were anxious not able to complete the materials in the syllabus on the existing curriculum, and finally, teachers were anxious that students could not answer questions on the national exam. This is because the 2013 curriculum had been determined by the central government, started from planning the lesson plans up to textbooks or teaching materials. So the teachers used the main textbooks to meet the syllabus on the curriculum and merely to make students able to answer the national exam.

In addition, teachers needed a textbook, and they adapted supplement from other materials to make a lesson perfect and interesting (Ansary and Babai, 2003). Therefore, the teacher should have the ability to adapt the textbook to make interesting learning for the student inside the teaching and learning process. This is in line with Richard (2001), the textbook leads to teachers more creative and attractive.

Based on the result, teachers in SMPN 23 Banjarmasin raised some issues about using textbooks inside the teaching and learning process. The problem found by teachers in teaching and learning in classroom activity were materials and activity, language level, and teaching aids.

For the materials and activities teachers preferred to encounter the problem by making some adaptation or used some supplementary materials in teaching such as external books and the internet. Richards and Rogers (1986) suggested that instructional materials are able to give contents specification in detail. They direct teachers on the intensity of coverage and the amount of attention demanded by certain content or pedagogical task. Therefore, the teacher often used supplementary material as additional information to make sure students be able to learn more inside the classroom.

Intensive Journal, Vol. 4(1), 2021 
Furthermore, Richards and Rogers (1986) stated that an adaptation is a strategy used by the teacher in using a textbook to make materials in the classroom more suitable in a particular context will be used. In this case, the teachers usually used different kinds of tasks and exercises from the external textbook with some other media such as pictures and videos from the internet.

Another finding shows that there was a language difficulty level in the textbook used. One of the teachers claimed that the language level in the textbook was slightly high for their students based on their students' abilities, so the students got difficulties with it. In this case, the teachers only used a traditional way to explain the book by asking them to open a dictionary and found the meaning of the sentence in the textbook. Sometimes the teacher also presented the book in her own language.

The other aspects that become the main concern of teaching English were related to the media or aids in the teaching and learning process. Teachers' found it difficult to obtain, because there were no media available on the textbook they used. To anticipate this difficulty, the teachers sometimes used the internet as a helper or just read the listening transcript orally by themselves. Since the school lacked facilities for media in the teaching and learning process, the teacher sought and made media by themselves.

Hence, the writer can conclude that the materials on textbook and adaptation materials helped the teachers and students in the learning and teaching process to be conducted in classroom activities. Also, it could be a guide in teaching. Thus, teachers should know what aspect can suit students' needs as well as the problem in teaching and learning for the evaluation activity. Besides, teachers should have the option of choose supplementary materials based on their particular needs in their own specific teaching situation. In addition, a professional teacher should attempt to solve the problem faced in using a textbook by themselves to make exciting teaching and learning the classroom.

\section{CONCLUSION}

Teachers used the textbooks as a guide in teaching and learning in the classroom. But they kept making some adaptation to it. The adapted strategies used by teachers in using textbooks were adding material and modifying the tasks. They modified the content when the students were not interested in the topic, and when teachers found inappropriate material, they would omit the material. Teachers did not use the main textbook only; they used other external textbooks and material in teaching. They used a textbook based on the student's needs.

Then, there are three main problems faced by English teachers at SMPN 23 Banjarmasin in using the textbook, namely, the problem concerning limited aids for teaching, lacks material inside the textbook, and higher language level for students. Despite this, the teachers always try to solve the problems encountered in using the textbook.

Intensive Journal, Vol. 4(1), 2021 


\section{REFERENCES}

Aminuddin, M. (2009). Analysis of teachers' use of English instructional materials: from preparation to implementation: A case study of English instructional material used by English teachers at STIA LAN Bandung. Bandung: Unpublished master's thesis, Universitas Pendidikan Indonesia.

Ansary, H., \& Babaii, E. (2003). Subliminal sexism in current ESL/EFL textbooks. Asian EFL Journal, 1-11.

Cunningsworth, A. (1995). Choosing your coursebook. Oxford: Heinemann.

Diniah, S. N. (2013). Teachers' Perceptions Towards the Use of English Textbook in EFL Classrooms. (A Descriptive Study of EFL Teachers at One Islami Senior High School in Cirebon). Journal of English and Education, 1 (1), 185-195.

Harmer, J. (2007). The Practise of English language Teaching. Edinburgh: Pearson Education Ltd.

Hutchinson, T., \& Torres, E. (1994). The textbook as agent of change. ELT Journal, 48(4), 315-328.

O'Neill, R. (1982). Why use textbooks? ELT Journal, 36(2), 104-111.

Richards, J. C. (2001). Curriculum development in language teaching. Cambridge: Cambridge University Press.

Richards, J. C., \& Rodgers, T. S. (1986). Approach and methods in language teaching. Cambridge: Cambridge University Press.

Spratt, M. A., \& Williams, M. (2005). The teaching knowledge test course. Cambridge: University Press.

Swales, J. (1980). ESP: The textbook problem. The ESP Journal, 11-23

Tomlinson, B. (1998). Materials development in language teaching. Cambridge: Cambridge University Press.

Tomlinson, B. (2008). English language learning materials: A critical review. London: Continum.

Ur, P. (1998). A course in language teaching: Practice and theory. Cambridge: Cambridge University Press.

Wahidah, S., Gunawan, A., Diyantari, Khatimah, Y. R. (2017). Bahasa Inggris "When English Rings a Bell” Kelas VIII (Edisi Revisi). Jakarta: Kementerian Pendidikan dan Kebudayaan. 